Estimating absolute pollen productivity for some European Tertiary-relict taxa

Filipova-Marinova, M.V., Kvavadze, E.V., Connor, S.E. and Sjögren, P.

This is a draft version of a manuscript published in Vegetation History and Archaeobotany 19: 351-364 (2010). Please note that there may be differences between this version and the final published version. The authors will be happy to provide copies on request. 
Mariana V. Filipova-Marinova, ${ }^{1}$ Eliso V. Kvavadze, ${ }^{2}$ Simon E. Connor ${ }^{3} *$ and Per Sjögren $^{4}$

\section{Estimating absolute pollen productivity for some European Tertiary-relict taxa}

Keywords: pollen dispersal models, absolute pollen production, pollen traps, palaeovegetation reconstruction, Georgia, Bulgaria

Tertiary-relict plants are survivors from the pre-Quaternary periods. Today, most European Tertiary relicts are confined to small, isolated stands distributed in the Mediterranean and Black Sea regions. In the past, however, the fossil record indicates that these species were probably distributed over large parts of the European continent and may have been important constituents of the vegetation. Little is known about their pollen representation, which limits our ability to reconstruct this past vegetation with any accuracy.

This paper draws on the results of pollen trapping experiments in Bulgaria and Georgia, where relict stands of Aesculus hippocastanum, Cercis siliquastrum, Fagus orientalis, Juglans regia and Pterocarya fraxinifolia are still in existence. We compared average pollen accumulation rates (PAR) to vegetation data from around the trapping locations to derive estimates of absolute pollen productivity using various pollen dispersal functions. Composite dispersal functions that model pollen components carried above the vegetation canopy and falling as rain provided better relationships between PAR and plant abundance than functions that considered only a single component or the 'trunk-space' component carried under the canopy.

A composite dispersal function with a simple model for regional pollen and the best overall correlation statistics gave the following estimates of absolute pollen

*Corresponding author. Tel.: +351 919499231; fax: +351 289800069; e-mail: sconnor@ualg.pt

${ }^{1}$ Department of Natural History, Varna Regional Museum of History, 41 Maria Louisa Blvd., Varna 9000, BULGARIA

${ }^{2}$ Davitashvili Institute of Paleobiology, National Museum of Georgia, 4 Niagvris St., 0108 Tbilisi, GEORGIA

${ }^{3}$ Centre for Marine and Environmental Research, FCMA, University of the Algarve, 8005-139 Faro, PORTUGAL

\footnotetext{
${ }^{4}$ Tromsø University Museum, Department of Natural Sciences, N-9037 Tromsø, NORWAY
} 
productivity (grains cm $\mathrm{yr}^{-1}$ with $1 \mathrm{SE}$ intervals): Carpinus betulus 19000-28700; Fagus orientalis 15600-20400; Juglans regia 27200-36200; Pterocarya fraxinifolia 182000-192600; Quercus spp. 21700-24800; Tilia begoniifolia 51600-68300; and T. tomentosa 14700-18200. These estimates were applied to fossil data from the Black Sea coast to reconstruct palaeovegetation using absolute and relative methods.

\section{Introduction}

In a world where the connections between climate and vegetation are becoming increasingly crucial to modelling the global atmospheric system, Quaternary pollen studies have a valuable role to play in the estimation of past vegetation cover (Edwards et al. 2007). Once content to produce pollen diagrams and interpret them in qualitative terms, palynologists are now called upon by palaeoclimate modellers and archaeologists to produce realistic, quantitative estimates of palaeovegetation density and composition.

Traditional pollen diagrams are basically a series of curves, each representing a single pollen type and its percentage contribution to the pollen sum at various moments in the past. Percentage data work well for a wide variety of purposes, but when used to estimate past vegetation cover, things become complicated. The most troublesome aspect of percentage data are their interdependence: if one taxon increases, all the others must decrease to accommodate it (Moore et al. 1991). This means that relationships between vegetation and pollen percentages are non-linear. In response, complex mathematical equations have been developed, allowing relative pollen productivity to be calculated from percentage data (Prentice 1986; Sugita 1993). Successful reconstruction of past vegetation based on fossil pollen percentages requires relative pollen productivity estimates for at least all the dominant taxa in the pollen record. This is not an especially difficult hurdle to jump if these taxa are common today. Once an extinct taxon appears in the fossil record, however, the use of relative pollen productivity becomes problematic.

The Quaternary history of the European flora is punctuated by extinctions (Svenning 2003). Less than a third of the tree genera that occurred in NW Europe at the end of the Tertiary period survive there today (Willis and Niklas 2004). Some of the taxa that disappeared from NW Europe can still be found growing in the Mediterranean and Black Sea regions, providing our main source of information on their ecology and pollen productivity. These populations occur in vegetation whose species composition may be entirely different to that of the fossil record, so the direct calculation of relative pollen productivity becomes, in such cases, unwieldy and unrealistic. While pollen productivity estimates from related species can be used for Tertiary-relict taxa, this is not ideal if we consider that species within the one genus may differ in their pollen productivity (Broström et al. 2008; Sjögren et al. 2008). 
Absolute pollen productivity estimates may provide the means to reconstruct past vegetation cover from pollen data that have no analogue in today's vegetation. Since each pollen taxon is dealt with independently, the absolute method should provide distance-weighted vegetation cover estimates for the taxa with known pollen productivity, so long as an absolute age model is available and pollen dispersal is correctly modelled. While the absolute method has several drawbacks (Sugita et al. 2009) and cannot 'raise Lazarus' to provide pollen productivity estimates for taxa that are completely extinct, we can make estimates from existing populations of Tertiaryrelicts in an effort to better characterise the vegetation cover of Europe in the late Tertiary and into the Quaternary. Even in the absence of an absolute age model, absolute estimates allow the calculation of relative pollen productivity estimates among taxa that do not occur together today.

In this paper we use the results of multi-year pollen trapping experiments in Tertiary-relict forests in the Black Sea region to provide preliminary estimates of absolute pollen productivity for Aesculus hippocastanum, Cercis siliquastrum, Carpinus betulus (syn. C. caucasica), Fagus orientalis, Juglans regia, Pterocarya fraxinifolia and Tilia begoniifolia (syn. T. caucasica, T. rubra). These taxa are represented in the European Quaternary fossil record and we anticipate that absolute pollen productivity estimates for some of these taxa may assist in their interpretation.

The ultimate aim of making pollen productivity estimates is to reconstruct vegetation cover for various moments in the past. Pollen loadings can be corrected for basin size (Prentice 1985; Sugita 1993) and used to estimate the cover of the taxon in question from fossil pollen accumulation rates. Such reconstructions can also provide a test for the various pollen dispersal functions, since reconstructed vegetation cover estimates should fall within the bounds of reality. Moreover, absolute reconstructions have the potential to provide estimates of vegetation cover where percentage-based methods are less effective, such as treeless environments (Sugita et al. 2009) and geological stages in which forest cover was less than it is today.

\section{The taxa and their role in the fossil record}

Aesculus hippocastanum, the Horse Chestnut, is a large deciduous tree with palmate leaves. It is the only European representative of its genus. Its present distribution is centred on the Balkan Peninsula, in the mountains of Greece, Bulgaria and Albania (Figure 1; Avtzis et al. 2007). The European fossil record demonstrates that Aesculus was much more widely distributed in the past, particularly during the Pliocene, when its range spread from North Africa to Northern Europe (Maley 1980; Postigo Mijarra et al. 2008). Pleistocene records are mostly confined to the Mediterranean basin, from Barcelona in the west through to Anatolia and the Caucasus in the east (Postigo Mijarra et al. 2008; Shatilova et al. 2008). Large amounts of Aesculus pollen (up to $15 \%$ ) have been recorded in Early Pleistocene sediments from Leffe, Italy (Ravazzi 2003). 
Cercis siliquastrum, the Judas Tree, is a member of the Fabaceae with a deciduous habit and ranging in size from a large shrub to a small tree. It is distributed through Western Asia and into Mediterranean Europe. Its pollen is poorly dispersed by wind (de Beaulieu 1972) and is very infrequently represented in the palynological record, although the macrofossil record indicates the Western Eurasian distribution of Cercis was greater during the Tertiary (Kolakovskii 1973; Mai 1989).

Fagus orientalis is the Oriental Beech, a deciduous tree growing 20-40 metres in height. It is found in relatively moist forests from the Eastern Mediterranean to the Caspian region, grading into F. sylvatica forests in the Balkans, Romania, Crimea and western Anatolia (Dolukhanov, 1989). Its importance in the European fossil record is perhaps considerable, since it has been suggested that Fagus pollen in European deposits during previous interglacials represents Fagus orientalis rather than $F$. sylvatica, which is now widespread in Central and Western Europe (Huntley and Birks 1983; Paffetti et al. 2007). Both species are, however, quite variable and may overlap genetically (Denk et al. 2002).

Pterocarya fraxinifolia (syn. P. pterocarpa), the Caucasian Wing-nut, is a large, hydrophilic tree with deciduous, compound leaves and pendulous flowering racemes that later develop into chains of winged fruits. Its main distribution is centred on the Caucasus region, with populations spread along the southern coast of the Black and Caspian Seas and an outpost in southern Turkey (Browicz 1982 ff.). In European pollen diagrams, Pterocarya has a special significance since it is regarded as an indicator par excellence of the Holsteinian interglacial (marine isotope stage 11) (Andrieu et al. 1997; Guiter et al. 2008). Values up to $9 \%$ are recorded in Holstenian-aged deposits in the La Côte record from the French Alps (Field et al. 2000) and even higher values in Early Pleistocene records from Spain and Italy (Ravazzi 2003; Leroy 2008).

Juglans regia, the Persian Walnut, is a large deciduous tree occurring throughout Western Eurasia and most frequently in cultivation. It was widespread during the Tertiary (Suc 1980), when it occurred in association with taxa now extinct in Europe: Tsuga, Carya and Taxodiaceae (Shatilova \& Mchedlishvili 1980). Pleistocene glaciations led to the almost complete extirpation of Juglans in Europe, though palynological data suggest that relict populations may have survived the last glaciation in Caucasian and Iberian refugia (Gogichaishvili 1984; Carrión \& Sánchez-Gómez 1992).

The other taxa dealt with here - Carpinus betulus, Tilia begoniifolia, $T$. tomentosa and Quercus spp. - are represented in Tertiary- and Quaternary-aged deposits from W Eurasia. They are not necessarily considered Tertiary-relict, but are included here because of their palynological significance and prevalence in the present-day vegetation. 


\section{Materials and methods}

\section{Pollen trapping}

Annual pollen trapping results are derived from thirteen locations: four in Bulgaria and nine in Georgia (Figure 1; Table 1; Kvavadze 1999). At each location, pollen traps were placed and collected annually according to the guidelines of the Pollen Monitoring Programme (Hicks et al. 2001). In Georgia, traps were placed randomly in different vegetation zones along an altitudinal transect; in Bulgaria, traps were placed within populations of Tertiary-relict trees to monitor these species. Pollen was identified and counted after the addition of Lycopodium spore tablets to enable calculation of pollen accumulation rates. Data are missing from some years when traps were stolen, lost, damaged or contaminated. The data used in calculations are the mean annual pollen accumulation rate (in grains $\mathrm{cm}^{-2} \mathrm{yr}^{-1}$; see Table 1). The use of average values compensates for inter-annual variability in pollen accumulation, mimicking the post-depositional processes that smooth out this variability in sediment records. The number of traps used to monitor each taxon varies from 1 to 13 (Table 1). Despite the small sample size, we include results from Aesculus and Cercis because they are the only available information on the pollen productivity of these taxa.

\section{Vegetation surveys}

In August 2009, the vegetation surrounding each of the traps was described in 12 concentric rings with a maximum diameter of $1,2.15,4.64,10,21.5,46.4,100,215$, 464, 1000, 2150 and $4640 \mathrm{~m}$ respectively (cf. van der Knaap et al., 2001). The use of exponentially increasing ring sizes accounts for the greater importance of pollen producers close to the site of deposition relative to those further away (Davis 2000). The absolute cover abundance of arboreal pollen producers (trees, shrubs and lianas) was estimated by eye during field walking for survey rings up to $1000 \mathrm{~m}$ in diameter. Vegetation rings between 1000 and $4640 \mathrm{~m}$ were estimated using a combination of local forestry data (Bulgaria), 2006 satellite imagery (Georgia), and on-the-ground observations (both countries). Beyond this distance, from $4640 \mathrm{~m}$ to $464 \mathrm{~km}$, vegetation cover was estimated from a 1:1000000 vegetation map of Bulgaria (Vulkov 1973) and a 1:1500000 forest map of Georgia (Dzhavakhishvili 1964). Vegetation data are represented in Figure 2.

\section{Theory of pollen dispersal}

Tauber's (1965) theory of pollen dispersal has generally been accepted as a realistic model for how pollen grains disperse from the vegetation to arrive at a study site. His model has three components: a 'trunk-space' component dispersed at low wind velocity $\left(0.5-1.5 \mathrm{~m} \mathrm{~s}^{-1}\right)$ within the vegetation's structure, a 'canopy' component carried by moderate winds $\left(2-6 \mathrm{~m} \mathrm{~s}^{-1}\right)$ above the vegetation, and a 'rain' component that is carried aloft by stronger winds and is mixed high in the atmosphere before being deposited either by rainfall or during still conditions. At least one of these components 
is responsible for aerial pollen deposition in any given place on Earth, even though the terminology was developed with European forests in mind.

The relative contribution of each component depends on several factors, amongst which vegetation structure and basin size are most important (Moore et al. 1991; Sugita 1993). Open vegetation and large basins are thought to be dominated by the 'rain' component, while closed forests and small basins may have a greater trunkspace component (Jacobson and Bradshaw 1981). Pollen may also arrive at a study site by direct deposition (the 'local' or 'gravity' component) and through inwash, which occurs when pollen grains are redeposited from one location to another (Prentice 1985; Moore et al., 1991). Pollen traps themselves can be attractive to pollen-bearing insects, so additional pollen may arrive in the trap by this means. For the sake of simplicity, only the three original components proposed by Tauber (1965) are considered in this paper, though the potential influence of the others should not be forgotten.

The diffusion of each of these pollen components is governed by a number of variables, including wind speed, turbulence, air humidity, vegetation density, the size and weight of the pollen and the height of its release from the parent plant. Several of these parameters can be simulated mathematically using the empirical particle diffusion model developed by Sutton (1953), which has found wide application and acceptance in the palynological literature (see Broström et al. 2008).

\section{Pollen dispersal functions}

In this paper we use Sutton's equation to determine the relative contribution of the various vegetation rings to the pollen accumulation rate in the trap. This contribution is modulated by the relative importance of the trunk-space, canopy and rain components of pollen deposition, so we have endeavoured to take these components into account using various dispersal functions (called 'composite dispersal functions', see Sjögren et al., this volume). We compare both composite and simple dispersal functions, summarised as follows:

- Dispersal function 1 (DF 1): Sutton's equation applied to the 'canopy' component with an injection height of $0 \mathrm{~m}$ (i.e. ground-level pollen source) and a wind speed of $3 \mathrm{~m} \mathrm{~s}^{-1}$;

- Dispersal function 2 (DF 2): Sutton's equation applied only to the 'rain' component with an injection height of $20 \mathrm{~m}$ and wind speed of $7 \mathrm{~m} \mathrm{~s}^{-1}$;

- Dispersal function 3 (DF 3): Sutton's equation applied to the 'trunk-space', 'canopy' and 'rain' components, i.e. the average of a trunk-space component with an injection height of $0.1 \mathrm{~m}$ and wind speed of $1 \mathrm{~m} \mathrm{~s}^{-1}$, a canopy component injected at $1 \mathrm{~m}$ at $4 \mathrm{~m} \mathrm{~s}^{-1}$ and a rain component injected at $20 \mathrm{~m}$ at $7 \mathrm{~m} \mathrm{~s}^{-1}$; 
- Dispersal function 4 (DF 4): Sutton's equation applied to the 'canopy' and 'rain' components with the same parameters as in function 3 (i.e. no trunkspace component). Both components are considered of equal importance, i.e. dispersal ratio $1: 1$;

- Dispersal function 5 (DF 5): Sutton's equation applied to the 'canopy' component with an injection height of $1 \mathrm{~m}$ and wind speed of $4 \mathrm{~m} \mathrm{~s}^{-1}$, with a 'rain' component fixed at $25 \%$ of pollen dispersal. This dispersal function differs from the one above in that the 'rain' component is not distanceweighted in any way - all trees within a $232 \mathrm{~km}$ radius of the pollen trap are assumed to contribute equally to the rain component.

Most previous studies have employed a single, ground-level source (e.g. DF 1) in dispersal functions based on Sutton's equation (e.g. Prentice 1985; Sugita et al. 1999; Sugita et al. 2009). One argument for this is that the forest canopy acts as the ground level, effectively trapping pollen, which then drops vertically below it (Prentice 1985). But as there is no empirical evidence that this actually is the case, it must be considered more an argument against the uncritical use of tree height as the elevation of pollen dispersal. A second reason for using a ground-level source is it removes the so-called 'skip distance' from an elevated pollen source: a short distance over which pollen deposition should theoretically increase before decreasing at greater range (Tauber 1965; Janssen 1966). Evidence for the skip distance phenomenon has been found in some cases (Rempe 1937; Persson 1955), but not all (Wright 1952; Wang et al. 1960), suggesting that plants do not behave as point sources (Janssen 1966). A ground-level source is appropriate for modelling dispersion of pollen from grasses, herbs and shrublets, and a ground-level source model performed well for these pollen types in the validation experiments of Nielsen (2004). The same experiments showed weaker model performance for arboreal pollen types, which, at least in theory, should be modelled using an elevated source. For this reason we compare ground-level and elevated source models for our analysis of Tertiary-relict trees.

The terminal velocity of pollen sedimentation under gravity is known as pollen fall speed. Large, heavy pollen grains tend to have higher fall speeds than smaller, lighter grains. This dispersal bias can be approximated by pollen fall speeds since plant species produce pollen grains that have a characteristic shape and size range (Sugita et al. 2009). Empirical fall speeds used in this paper are listed in Table 2 and are derived from a number of published sources. Where more than one fall speed was reported in the literature (due to differences in experimental apparatus and pollen grain size - see Jackson \& Lyford 1999), we used a simple linear regression between pollen size and fall speed to determine the most appropriate value to use. In the absence of a published fall speed (which is generally the case for Tertiary-relict taxa), we applied the fall speed of similarly sized and shaped pollen based on the measurements of Beug (2004). 
Each of the dispersal functions provides an estimate of distance-weighted plant abundance (DWPA) when applied to the vegetation data. This value can then be compared to average pollen accumulation rates (PARs) from the traps. Pollen productivity estimates can be calculated as the slope coefficient in a linear least-squares regression between DWPA and PAR. Pollen originating from beyond the study area constitutes a background component quantified by the y-intercept of the regression. Theoretically, the background level should eventually reach zero if the dispersal function is appropriate and the study area used to derive DWPA is large enough (Sjögren et al. this volume). The 'best' dispersal function should be one that exhibits a strong positive relationship between PAR and DWPA, as well as one that has a minimal level of background pollen when applied to DWPA from a large study area.

The resulting estimates for each dispersal function were assessed through comparison of background pollen levels, correlation statistics and the reduction in correlation induced by setting a zero y-intercept. Analysis of variance (ANOVA) was used to determine correlation coefficients, $p$-values and standard errors for each PAR:DWPA regression.

\section{Reconstruction}

The reconstruction method used here (Sjögren et al. 2008) requires a number of assumptions, i.e. that the pollen productivity of each taxon has not changed through time, that atmospheric conditions for pollen deposition were the same in the past as now, that the pollen represents the species found in today's forests rather than a closely related extinct one, that basin size has remained constant or that changes can be corrected for, that pollen accumulation rates have been accurately determined, that all of the pollen is contributed from vegetation within a specified distance of the site of deposition, and that vegetation within this distance is homogenous.

We tested the reconstruction technique on pollen data from a site on the Black Sea coast of Georgia (Figure 1). Ispani-II is a Sphagnum-dominated mire approximately $1.2 \mathrm{~km}$ in diameter. Since basin size has an important impact on pollen deposition (Prentice 1985; Sugita et al. 2009), absolute pollen productivity estimates were corrected for basin-size bias using the elevated source equation given by Prentice (1985, equation 1A) with parameters from each of the dispersal functions. This gave potential 'pollen loadings' (sensu Sugita et al. 2009), which, in this context, represent the amount of pollen that would be deposited at the centre of the mire if an area extending $1000 \mathrm{~km}$ in all directions was completely covered by the taxon in question. The period from 1000-100 cal. BP was chosen for reconstruction since it represents a stable, forested phase in Ispani-II's vegetation history, with rapid accumulation $(\sim 0.4$

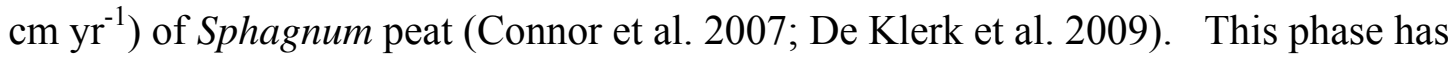
average pollen accumulation rates of approximately 10000 grains $\mathrm{cm}^{-2} \mathrm{yr}^{-1}$ for Fagus, 7000 for Carpinus and 3000 for Quercus (estimated from De Klerk et al. 2009), and 2000 for Pterocarya (from Connor et al. 2007). Reconstructed vegetation cover was 
estimated by dividing each taxon's mean pollen accumulation rate in the sediments by its potential pollen loading.

Reconstructions were also performed using correction factors relative to the pollen productivity of Quercus, which was chosen because of its appearance in all of the pollen traps, its ubiquity in pollen diagrams from the Black Sea region and its consistent reflection of DWPA (Table 3) despite being represented by several different species.

\section{Results}

When each of the dispersal functions is applied, the results indicate that Pterocarya fraxinifolia consistently has the highest pollen productivity, followed by Tilia begoniifolia (Table 3 ). Pollen productivity $\left(\mathrm{P}_{\mathrm{c}}\right)$ values vary considerably between the five dispersal functions, especially for the taxa represented at only one or two sites: Aesculus and Cercis. In some cases there is no relationship between PAR and DWPA, indicated by negative $\mathrm{P}_{\mathrm{c}}$ values and low correlation coefficients.

Background pollen $\left(\mathrm{C}_{\mathrm{r}}\right)$ is generally higher for DFs 1 and 3 compared to DFs 2, 4 and 5. Among taxa, Carpinus and Fagus exhibit the most variation. Negative values for this background component may indicate that the cover of some taxa has been overestimated for the outer vegetation rings, although the small reduction in $r$-values when a zero y-intercept is imposed (Table 3 ) suggests that this is probably not important.

In terms of correlation coefficients, composite dispersal functions DF 4 and DF 5 consistently produced good PAR:DWPA relationships and generally lower standard errors. DFs 1 and 3, which use a low injection-height component, perform well for taxa represented on a local scale (e.g. Juglans, Pterocarya and Tilia begoniifolia), but very poorly for regional forest dominants such as Carpinus and Fagus. DF 2 produces significant results only for these regionally important trees. Differences in correlation coefficients between pollen productivity $\left(\mathrm{P}_{\mathrm{c}}\right)$ and absolute pollen productivity (APP) tend to be less for DFs 2, 4 and 5 (Table 3), suggesting that these account for background pollen better than the other dispersal functions tested.

Relative pollen productivity (RPP) estimates compared to Quercus are given at the bottom of Table 3. The dispersal functions that incorporate a low injection component tend to produce lower RPP estimates relative to Quercus than those that upweight the canopy and rain components, the most extreme example being DF 2 .

Figure 4 shows reconstructions for Fagus orientalis, Carpinus betulus, Quercus and Pterocarya fraxinifolia cover around Ispani-II, produced by dividing pollen accumulation rates by potential pollen loadings (Table 4). Absolute reconstruction based on a ground-level source (DF 1) yields an extremely high mean estimate of absolute plant cover (1400\%). Other dispersal functions produce lower estimates: $98 \%$ 
(DF 2), 302\% (DF 3), 155\% (DF 4) and 177\% (DF 5). Relative reconstructions tend to be similar for all of the dispersal functions tested, though there are some specific differences: DF 1 gives the highest estimates for Fagus, DF 2 for Quercus, and DF 3 for Carpinus, while both DFs 4 and 5 give intermediate values for all taxa (Figure 4).

\section{Discussion}

The application of different pollen dispersal models to pollen accumulation data from Bulgaria and Georgia has produced a suite of highly variable results. Some of this variability can be explained by the small datasets used, and tends to be more severe for taxa that are represented at few sites (i.e. Aesculus, Cercis, Juglans and Pterocarya). Widespread taxa produce more consistent results, the best example being Quercus. The variability is also attributable to the deliberate choice of contrasting dispersal functions, each of which is discussed briefly below:

- Dispersal function 1: Sutton's equation applied to the 'canopy' component of pollen dispersion at ground-level generally produced high pollen productivity estimates. By upweighting local vegetation, DF 1 produced statistically significant PAR:DWPA relationships for taxa such as Juglans, Quercus, Pterocarya and Tilia begoniifolia, but performed poorly for the regional dominants, Fagus and Carpinus. High background pollen $\left(\mathrm{C}_{\mathrm{r}}\right)$ values are associated with this dispersal function and thus APP estimates tend to have large standard errors and lower correlation coefficients. Quantitative reconstructions based on this dispersal function overestimated palaeovegetation cover to an unrealistic degree.

- Dispersal function 2: Sutton's equation applied only to the 'rain' component produced highly variable pollen productivity estimates. For taxa occurring in only one or two locations, pollen productivity estimates are extremely high and have large errors. However, this dispersal function performed surprisingly well for widespread taxa (Carpinus, Fagus, Quercus and Tilia) given the imprecision of regional vegetation data. This dispersal function was the only one to produce a mean estimate of absolute cover below $100 \%$ when applied to fossil data.

- Dispersal function 3: Sutton's equation applied to the 'trunk-space', 'canopy' and 'rain' components produced low estimates of pollen productivity. Like DF 1, this dispersal function was suitable for locally represented taxa but was unable to account for background pollen from Fagus and Carpinus. Absolute reconstructions overestimated palaeovegetation cover, especially for these two taxa. 
- Dispersal function 4: Sutton's equation applied to the 'canopy' and 'rain' components yielded intermediate pollen productivity estimates for all taxa except Pterocarya. Background pollen values were relatively low, such that $\mathrm{P}_{\mathrm{c}}$ and APP estimates are almost identical. This dispersal function gave the best PAR:DWPA correlation for Fagus, but slightly weaker correlations for Juglans and Tilia begoniifolia. Reconstructions overestimated palaeovegetation cover, but to a lesser degree than DFs 1, 3 and 5.

- Dispersal function 5: Sutton's equation applied to the 'canopy' component with an unweighted 25\% 'rain' component produced similar or slightly lower pollen productivity estimates compared to DF 4 . This was the only dispersal function for which all PAR:DWPA correlations were statistically significant at the $p<0.05$ level. Background pollen and standard errors were both low. Palaeovegetation reconstructions were similar to those of DF 4.

To summarise, the dispersal functions that involve a low $(0-0.1 \mathrm{~m})$ injectionheight component appear to perform adequately for taxa that occur locally or infrequently in the landscape but perform very poorly for widespread taxa. The opposite tends to be true for dispersal functions that comprise a single 'rain' component from a highly elevated source (e.g. DF 2). Based on our analysis, the best results come from composite dispersal functions that combine a 'canopy' component injected at moderate elevation (e.g. $1 \mathrm{~m}$ ) with some form of 'rain' component. Dispersal functions 4 and 5 satisfy the criterion of producing strong positive relationships between PAR and DWPA whilst having minimal levels of background pollen.

The ability of composite dispersal functions to account for background pollen can be illustrated by Fagus orientalis (Figure 3). Fagus pollen accumulation rates of 10000 grains $\mathrm{cm}^{-2} \mathrm{yr}^{-1}$ are recorded in Lagodekhi trap 5, where Fagus orientalis is subdominant in the vegetation to Carpinus betulus, Acer velutinum, Tilia begoniifolia and Corylus colurna within $1 \mathrm{~km}$ of the trap. In Bulgaria, pollen accumulation rates around 3000 grains $\mathrm{cm}^{-2} \mathrm{yr}^{-1}$ occur in pure Fagus orientalis forests. If only vegetation within $1 \mathrm{~km}$ of the trap is considered, this means the Georgian populations of Fagus orientalis produce approximately nine times more pollen than the Bulgarian ones. Although differences in pollen productivity occur between regions (Bröstrom et al. 2008), the difference can also be explained by pollen inputs at a regional scale, since $50 \%$ of Georgian forests are dominated by Fagus orientalis compared to a tiny percentage in Bulgaria (Dzhavakhishvili 1964; Vulkov 1973). Dispersal functions that combine both 'rain' and 'canopy' components (e.g. DFs 4 and 5) produce better PAR:DWPA relationships for Fagus.

It could be argued that Sutton's equation is not suited to modelling the 'rain' component of pollen deposition, even though in certain cases it appears to produce reasonable results. Pollen rain should, in theory, be the same for all sites in a study area and contain pollen from plants both near and far from the site of pollen deposition 
(Andersen 1970). Compared to the 'canopy' and 'trunk-space' components, this rain component is thought to be deposited in a different way - through incorporation into raindrops or gravitational settling - so the use of a dispersal model based on wind diffusion is also open to question. Dispersal function 5, with its 'rain' component being a simple average of regional plant abundance, probably simulates this effect, though other models for rain-out (e.g. Chamberlain 1975) could be tested. Another important consideration is the assumption that each component contributes equally to overall pollen productivity. Dispersal functions 3 and 4 give equal weight to each component, but in reality there may be differences and these may be taxon- or region-specific (see Sjögren et al., this volume).

Any dispersal function that incorporates an elevated pollen source remains afflicted by the 'skip distance' problem, i.e. that the vegetation immediately surrounding the pollen trap is assumed to contribute nothing to the pollen loading. In the composite dispersal functions applied here we solved this by applying a relatively low injection height $(1 \mathrm{~m})$ for the 'canopy' component, which limits the skip distance to around $5 \mathrm{~m}$, approximately the same size as the smallest forest gaps in which most traps are located. Using a ground-level pollen source (e.g. DF 1) removes the skip distance altogether, but tends to produce very high estimates of pollen productivity because the majority of pollen deposition is modelled to occur within a few metres of the source plant (cf. Sjögren et al. 2008). Empirical investigations have yet to provide unequivocal evidence for the existence or absence of the skip distance phenomenon in the real world. From a methodological standpoint, however, it would be preferable to place pollen traps randomly in the vegetation (Broström et al. 2008) rather than directly beside target species. A random sampling design has the advantage of limiting skip-distance problems, avoiding data noise from direct pollen deposition (the 'gravity' component) and producing a more robust and versatile dataset.

Further testing is required to properly evaluate pollen dispersal functions and care must be exercised when applying pollen productivity estimates. Pollen fall speeds are, in some cases, approximations instead of experimentally determined values. Pollen productivity estimates for Cercis and Aesculus have a large error since they are based on 1-2 sites and cannot be assessed statistically. Standard error estimates for other taxa are minimum values since they apply only to the regressions and do not take into account errors arising from the vegetation data, PAR calculations, pollen fall speeds, variability in pollen production and other parameters such as wind. Although errors may be calculated from inter-annual PAR variability alone (e.g. Sugita et al. 2009), much of this variation is climatically induced and does not represent variations in plant abundance (Autio \& Hicks 2004; Huusko \& Hicks 2009). Additional study is needed to locate and quantify sources of error in pollen productivity estimations based on long-term pollentrap data.

Care must also be taken because our estimates are all derived from mountainous areas and these areas are known to have special characteristics when it comes to pollen 
representation and dispersal (Markgraf 1980; Kvavadze 1993). Mountains generally have more bioclimatic variety than plains and the close juxtaposition of various types of zonal vegetation means that wind can easily transport pollen to different vegetation zones. How this affects absolute pollen productivity estimation is not clear. As well as being mountainous, the study sites are all isolated refugia that may not be perfect analogues for palaeoenvironmental interpretation. Refugia usually have special microclimatic characteristics that distinguish them from the surrounding areas where relict taxa did not survive (Svenning 2003). One cannot assume that the climate that prevailed when these taxa were abundant was the same as that of their modern refugia. Today's populations of Tertiary-relict taxa may produce more or less pollen than their ancestors in response to climatic stress, declining genetic diversity and differences in vegetation structure, density and maturity.

Absolute pollen productivity estimates can be used to reconstruct palaeovegetation, but doing so invites a whole host of practical, methodological and theoretical problems (Sugita et al. 2009). This being the case, reconstructions produced by dispersal functions other than the ground-level source model are encouraging. Factors discussed in the foregoing paragraphs may help explain the overestimation of palaeovegetation cover by composite dispersal functions. Pollen accumulation rates for the Ispani-II mire are extremely high, perhaps because of unseen errors in the age-depth model, possible differences in pollen trapping efficiency between Sphagnum-Molinia vegetation and Tauber traps, or the fact that Ispani-II is located in a coastal zone with exceptionally high annual rainfall $(2365 \mathrm{~mm})$, while the trapping locations in Lagodekhi $(1000-1900 \mathrm{~mm})$ and Bulgaria $(700-1000 \mathrm{~mm})$ are near the bioclimatic limit for Colchic vegetation. Estimates from this method are absolute, so one could expect total vegetation cover in excess of $100 \%$ from the multi-layered forests that occur near Ispani-II (Denk et al., 2001). In any case, it would be desirable to trial absolute reconstructions on pollen records from other sites.

Relative reconstructions produced from the same estimates yielded remarkably consistent results for all four taxa (Figure 4). The reconstructions themselves accord with previous interpretations of pollen data from the Ispani-II site (Connor et al. 2007; De Klerk et al. 2009), although Pterocarya's importance in the vegetation may have been overstated. If the Georgian data is taken as representative of Pterocarya's pollen productivity in general, then occurrences in the Pleistocene fossil record may require reinterpretation: Pterocarya's past abundance was probably less than previously assumed.

Few data are available for comparing different estimates of absolute pollen productivity for the taxa studied here. In relative terms, all the dispersal functions tested gave estimates for Carpinus and Fagus that fall between values reported for the Swiss Plateau and Southern Sweden (Sugita et al. 1999; Soepboer et al. 2007; Broström et al. 2008), though it should be remembered that our estimates are for Fagus orientalis, not $F$. sylvatica. DF 5, a composite dispersal function with a simple model for regional 
pollen and the best overall correlation statistics, gives the following estimates (in grains $\mathrm{cm}^{-2} \mathrm{yr}^{-1}$ ) of absolute pollen productivity, with SE intervals : Carpinus betulus 1900028700; Fagus orientalis 15600-20400; Juglans regia 27200-36200; Pterocarya fraxinifolia 182000-192600; Quercus spp. 21700-24800; Tilia begoniifolia 5160068300; and Tilia tomentosa 14700-18200. We hope that these preliminary estimates will form the basis for further testing, validation and improvement in the future.

\section{Conclusions}

This paper is a first attempt to derive estimates of absolute pollen productivity and to better reconstruct the past distribution and dynamics of some Tertiary-relict elements from the European fossil record.

Several different pollen dispersal models, incorporating the various components of pollen deposition, were used to derive the estimates, yielding variable results. Composite dispersal functions that combine both 'canopy' and 'rain' components provided strong relationships between pollen accumulation rates and distance-weighted plant abundance, as well as having a minimal level of background pollen when applied to vegetation data from a large area.

Using these dispersal functions we were able to estimate absolute and relative pollen productivity for some of the species studied, i.e. Fagus orientalis, Carpinus betulus, Pterocarya fraxinifolia, Juglans regia, Tilia begoniifolia, T. tomentosa and Quercus spp. The results may assist in the interpretation of fossil pollen records, although the large number of uncertainties still surrounding pollen dispersal means that the estimates must be used with caution. An important outcome is that Pterocarya is strongly over-represented in pollen data compared to vegetation.

In the present investigation we managed to reconstruct relative palaeovegetation with a high degree of consistency between methods. It seems clear that, with a better understanding of pollen dispersion, absolute methods hold great promise for quantitative reconstructions of palaeovegetation.

\section{Acknowledgements}

The authors would like to dedicate this paper to Sheila Hicks, for her vision in establishing the Pollen Monitoring Programme (PMP) and her untiring enthusiasm in guiding its development over the years. Many thanks to the local directors of the State Forestry Agency of Bulgaria for allowing us to use their forest composition data, to Shota Eriashvili for his invaluable assistance with fieldwork, to Antti Huusko for practical advice on applying Sutton's equation, to Christoph Sperisen for helping with the map, and to Marta for her patience during vegetation surveys in Lagodekhi. We are 
grateful to Pim van der Knaap for his constant encouragement and to Anne Birgitte Nielsen, Thomas Giesecke and an anonymous reviewer for their helpful comments on the manuscript, which is a contribution to the PMP and to IGCP project 521.

\section{References}

Andersen ST (1970) The relative pollen productivity and pollen representation of North European trees, and correction factors for tree pollen spectra, determined by surface pollen analyses from forests. Danmarks Geologiske Undersøgelse 96:199

Andrieu V, Field MH, Ponel P, Guiot J, Guenet P, de Beaulieu JL, Reille M, MorzadecKerfourn MT (1997) Middle Pleistocene temperate deposits at Dinge, Ille-etVilaine, northwest France: pollen, plant and insect macrofossil analysis. Journal of Quaternary Science 14:309-331

Autio J, Hicks S (2004) Annual variations in pollen deposition and meteorological conditions on the fell Aakenustunturi in northern Finland: Potential for using fossil pollen as a climate proxy. Grana 43:31-47

Avtzis ND, Avtzis DN, Vergos SG, Diamandis S (2007) A contribution to the natural distribution of Aesculus hippocastanum (Hippocastanaceae) in Greece. Phytologia Balcanica 13:183-187

de Beaulieu, JL (1972) Analyses polliniques des tourbes éémiennes de Saint-Paul-lezDurance (Bouches-du-Rhône). Bulletin de l'Association française pour l'étude du Quaternaire 3:195-206

Beug H-J (2004) Leitfaden der Pollenbestimmung für Mitteleuropa und angrenzende Gebiete. Verlag Dr Friedrich Pfeil, München

Bodmer H (1922) Uber den Windpollen. Natur \& Techn. 3:294-298

Broström A, Nielsen AB, Gaillard M-J, Hjelle K, Mazier F, Binney H, Bunting J, Fyfe R, Meltsov V, Poska A, Räsänen S, Soepboer W, von Stedingk H, Suutari H, Sugita S (2008) Pollen productivity estimates of key European plant taxa for quantitative reconstruction of past vegetation: a review. Vegetation History and Archaeobotany 17:461-478

Browicz K (1982 ff.) Chorology of Trees and Shrubs in South-West Asia and Adjacent Regions (6 vols.). Polish Scientific Publishers, Warszawa

Carrión JS, Sánchez-Gómez P (1992) Palynological data in support of the survival of walnut (Juglans regia L.) in the western Mediterranean during last glacial times. Journal of Biogeography 19:623-630 
Chamberlain AC (1975) The movement of particles in plant communities. In: Monteith JL (ed) Vegetation and the Atmosphere 1, Academic Press, New York, pp 155203

Connor SE, Thomas I, Kvavadze EV (2007) A 5600-yr history of changing vegetation, sea levels and human impacts from the Black Sea coast of Georgia. The Holocene 17:25-36

Davis MB (2000) Palynology after Y2K - understanding the source area of pollen in sediments. Annual Review of Earth and Planetary Science 28:1-18

De Klerk P, Haberl A, Kaffke A, Krebs M, Matchutadze I, Minke M, Schulz J, Joosten H (2009) Vegetation history and environmental development since ca $6000 \mathrm{cal}$ yr BP in and around Ispani 2 (Kolkheti lowlands, Georgia). Quaternary Science Reviews 28:890-910

Denk T, Frotzler N, Davitashvili N (2001) Vegetational patterns and distribution of relict taxa in humid temperate forests and wetlands of Georgia (Transcaucasia). Biological Journal of the Linnean Society 72:287-332

Denk T, Grimm G, Stögerer K, Langer M, Hemleben V (2007) The evolutionary history of Fagus in western Eurasia:evidence from genes, morphology and the fossil record. Plant Systematics and Evolution 232:213-236

Dolukhanov AG (1989) Lesnaia rastitel'nost' Gruzii, I (Forest vegetation of Georgia, volume I). Metsniereba, Tbilisi

Dyakowska J (1936) Researches on the rapidity of the falling down of pollen of some trees. Bull. Acad. Polon. Sci. B1:155-168.

Dyakowska J, Zurzycki, J (1959) Gravimetric studies on pollen. Bull. Acad. Polon. Sci. 7:11-16

Dzhavakhishvili AN (ed) (1964) Atlas Gruzinskoi SSR (Atlas of the Georgian SSR). GUGK, Tbilisi

Edwards TL, Crucifix M, Harrison SP (2007) Using the past to constrain the future: how the palaeorecord can improve estimates of global warming. Progress in Physical Geography 31:481-500.

Eisenhut G (1961) Untersuchungen über die Morphologie und Ökologie der Pollenkörner heimischer und fremdländischer Waldbäume. Forstwiss. Forsch. 15:1-68.

Field MH, de Beaulieu JL, Guiot J, Ponel P (2000) Middle Pleistocene deposits at La Cote, Val-de-Lans, Isere department, France: plant macrofossil, palynological 
and fossil insect investigations. Palaeogeography Palaeoclimatology Palaeoecology 159:53-83

Gogichaishvili, LK (1984) Vegetational and climatic history of the western part of the Kura River basin. In: Bintliff JL, van Zeist W (eds) Paleoclimates, Paleoenvironments, and Human Communities in the Eastern Mediterranean Region in Later Prehistory. B.A.R. International Series, Oxford, pp. 325-341

Guiter F, Andrieu-Ponel V, de Beaulieu JL, Nicoud G, Ponel P, Blavoux B, Gandouin E (2008) Palynostratigraphy of some Pleistocene deposits in the Western Alps: a review. Quaternary International 190:10-25

Hicks S, Tinsley H, Huusko A, Jensen C, Hättestrand M, Gerasimides A, Kvavadze E (2001) Some comments on spatial variation in arboreal pollen deposition: first records from the Pollen Monitoring Programme (PMP). Review of Palaeobotany and Palynology 117:183-194

Huntley B, Birks HJB (1983) An Atlas of Past and Present Pollen Maps for Europe: 0 13000 years ago. Cambridge University Press, Cambridge

Huusko A, Hicks S (2009) Conifer pollen abundance provides a proxy for summer temperature: evidence from the latitudinal forest limit in Finland. Journal of Quaternary Science 24:522-528

Jacobson GL Jr, Bradshaw RHW (1981) The selection of sites for palaeovegetational studies. Quaternary Research 16:80-96

Knoll F (1932) Über die Fernverbreitung des Blütenstaubes durch den Wind. Forschungen und Fortschritte: Nachrichtenbl. Deutsch. Wiss. Tech. 8:301-302

Kolakovskii AA (ed) (1973) Katalog iskopaemykh rastenii Kavkaza (Catalogue of fossil plants of the Caucasus). Metsniereba, Tbilisi

Kvavadze EV (1993) On the interpretation of subfossil spore-pollen spectra in the mountains. Acta Palaeobotanica 33:347-360

Kvavadze, EV (1999) The first results of the pollen monitoring programme in the Caucasus mountains (Georgia). Acta Palaeobotanica 39:171-177

Leroy SAG (2008) Vegetation cycles in a disturbed sequence around the CobbMountain subchron in Catalonia (Spain). Journal of Paleolimnology 40:851-868

Mai DH (1987) Development and regional differentiation of the European vegetation during the Tertiary. Plant Systematics and Evolution 162:79-91

Maley J (1980) Les changements climatiques de la fin du Tertiaire en Afrique: leur conséquence sur l'apparition du Sahara et de sa végétation. In: Williams MAJ, 
Faure H (eds) The Sahara and the Nile: Quaternary environments and prehistoric occupation in northern Africa. AA Balkema, Rotterdam, pp. 63-86

Markgraf V (1980) Pollen dispersal in a mountain area. Grana 19:127-146

Moore PD, Webb JA, Collinson ME (1991) Pollen Analysis. Blackwell Science Publishers, Oxford

Nielsen AB (2004) Modelling pollen sedimentation in Danish lakes at c. AD 1800: an attempt to validate the POLLSCAPE model. Journal of Biogeography 31:16931709

Paffetti D, Vettori C, Caramelli D, Vernesi C, Lari M, Paganelli A, Paule L, Giannini R (2007) Unexpected presence of Fagus orientalis complex in Italy as inferred from 45,000-year-old DNA pollen samples from Venice lagoon. BMC Evolutionary Biology 7(suppl. 2):S6

Persson A (1955) Frequenzen von Kiefernpollen in Südschweden in 1953 und 1954. Forstgenetik und Forstpflanzenzucht 4:129-137

Postigo Mijarra JM, Manzaneque FG, Morla C (2008) Survival and long-term maintenance of Tertiary trees in the Iberian Peninsula during the Pleistocene: first record of Aesculus L. (Hippocastanaceae) in Spain. Vegetation History and Archaeobotany 17:351-364

Prentice IC (1985) Pollen representation, source area, and basin size: toward a unified theory of pollen analysis. Quaternary Research 23:76-86

Prentice IC (1986) Multivariate methods for data analysis. In: Berglund BE (ed) Handbook of Holocene Palaeoecology and Palaeohydrology. John Wiley and Sons, Chichester, pp. 775-797

Ravazzi C (2003) Gli antichi bacini lacustri e i fossili di Leffe, Ranica e Pianico-Sèllere (Prealpi Lombarde). Istituto per la Dinamica dei Processi Ambientali, Bergamo.

Rempe H (1937) Untersuchungen über die Verbreitung des Blütenstaubes durch die Luftströmungen. Planta 27: 93-147.

Shatilova I, Rukhadze L, Mchedlishvili N (2008) The results of palaeobotanical investigations of Meotian deposits of Western Georgia. In: Vekua A (ed) Problems of Palaeobiology, volume III. Georgian National Museum press, Tbilisi, pp. 23-34

Shatilova II, Mchedlishvili NS (1980) Palinologicheskie kompleksy Chaudinskikh otlozhenii Zapadnoi Gruzii i ikh stratigraficheskoe znachenie (Palynological complexes of Chaudian sediments in Western Georgia and their stratigraphic significance). Metsniereba, Tbilisi 
Sjögren P, Connor SE, van der Knaap WO, van Leeuwen JFN (this volume) An evaluation of composite dispersal functions for estimating absolute pollen productivity in the Swiss Alps. Vegetation History and Archaeobotany

Sjögren P, van der Knaap WO, Huusko A, van Leeuwen JFN (2008) Pollen productivity, dispersal, and correction factors for major tree taxa in the Swiss Alps based on pollen-trap results. Review of Palaeobotany and Palynology 152:200-210.

Soepboer W, Sugita S, Lotter AF, van Leeuwen JFN, van der Knaap WO (2007) Pollen productivity estimates for quantitative reconstruction of vegetation cover on the Swiss Plateau. The Holocene 17:65-77

Suc, JP (1980) Origin and evolution of the Mediterranean vegetation and climate in Europe. Nature 307:429-432.

Sugita S (1993) A model of pollen source area for an entire lake surface. Quaternary Research 39:239-244

Sugita S, Gaillard M-J, Broström A (1999) Landscape openness and pollen records: a simulation approach. The Holocene 9:409-421

Sugita S, Hicks S, Sormunen H (2009) Absolute pollen productivity and pollenvegetation relationships in northern Finland. Journal of Quaternary Science. DOI:10.1002/jqs.1349

Sutton OG (1953) Micrometeorology. McGraw-Hill, New York

Svenning J-C (2003) Deterministic Plio-Pleistocene extinctions in the European cooltemperate tree flora. Ecology Letters 6:646-653

Tauber H (1965) Differential pollen dispersion and the interpretation of pollen diagrams. Danmarks Geologiske Undersøgelse, II Række: 89.

van der Knaap WO, van Leeuwen JFN, Ammann B (2001) Seven years of annual pollen influx at the forest limit in the Swiss Alps studied by pollen traps: relations to vegetation and climate. Review of Palaeobotany and Palynology 117:31-52

Vulkov I (ed) (1973) Atlas Narodna Republika Bulgariia (Atlas of the People's Republic of Bulgaria). GUGK, Sofia

Wang C-W, Perry TO, Johnson AG (1960) Pollen dispersion of slash pine (Pinus elliottii Engelm.) with special reference to seed orchard management. Silvae Genetica 9:78-86

Willis KJ, Niklas KJ (2004) The role of Quaternary environmental change in plant macroevolution: the exception or the rule? Philosophical Transactions of the Royal Society of London B359:159-172 
Wright JW (1952) Pollen dispersion of some forest trees. Northeastern Forest

Experiment Station Paper No. 46, US Department of Agriculture, Upper Darby PA, 42 pp. 


\section{Tables}

Table 1. Site details for pollen trapping locations used in this study. The number of years of data collection is shown along with the average annual pollen accumulation rate (PAR) for that period. PAR values are reported only for sites where source plants were encountered in field surveys. Taxon codes: Aes - Aesculus hippocastanum; Car Carpinus betulus (syn. of C. caucasica); Cer - Cercis siliquastrum; Fag - Fagus orientalis; Jug - Juglans regia; Pte - Pterocarya fraxinifolia; Que - Quercus spp.; Til Tilia $\left({ }^{t}=T\right.$. tomentosa,${ }^{b}=T$. begoniifolia $)$. Site locations supersede those reported previously.

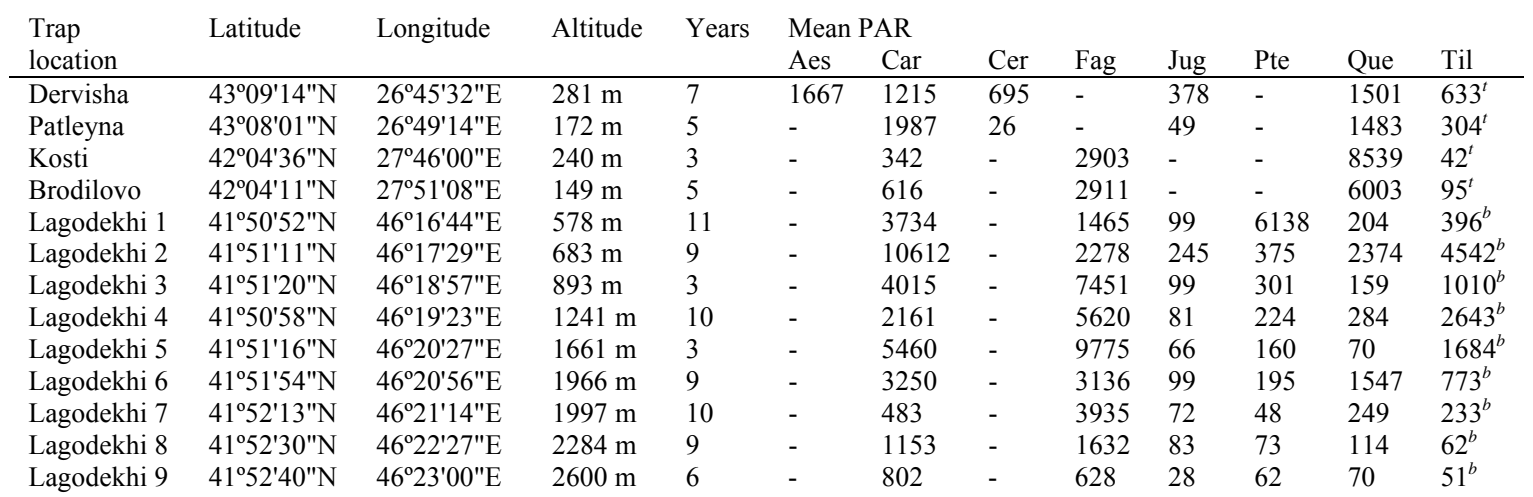

Table 2. Pollen fall speeds adopted in this paper. The fall speed for Juglans is the middle of the range (i.e. 0.029-0.044 $\mathrm{m} \mathrm{s}^{-1}$ ) given by Bodmer (1922).

\begin{tabular}{llll} 
Pollen type & Taxon used & Fall speed $\left(\mathrm{m} \mathrm{s}^{-1}\right)$ & Source \\
\hline Aesculus & Quercus robur & 0.029 & Knoll, 1932 \\
Carpinus & Carpinus betulus & 0.042 & Eisenhut, 1961 \\
Cercis & Taxus baccata & 0.023 & Dyakowska, 1936 \\
Fagus & Fagus sylvatica & 0.0603 & Dyakowska, 1936 \\
Juglans & Juglans sp. & 0.0365 & Bodmer, 1922 \\
Pterocarya & Carpinus betulus & 0.042 & Eisenhut, 1961 \\
Quercus & Quercus robur & 0.035 & Eisenhut, 1961 \\
Tilia & Tilia cordata & 0.0324 & Dyakowska \& Zurzycki, 1959
\end{tabular}

Table 3. Results of applying various dispersal functions (DF) to pollen trap and vegetation data from Bulgaria and Georgia (see text). $\mathrm{P}_{\mathrm{c}}$ - pollen productivity (slope coefficient of linear regression of PAR and DWPA values); SE - standard error of mean PAR; $\mathrm{C}_{\mathrm{r}}$ - background pollen (y-intercept of linear equation); APP - absolute pollen productivity (assuming zero background pollen input); Correlation difference difference between correlation coefficients for $\mathrm{P}_{\mathrm{c}}$ and APP regressions; RPP - relative pollen productivity for APP values relative to Quercus. N.B. No $r$-values are given for Aesculus and Cercis on account of being represented at only one or two sites. 
DF 1

DF 2

DF 3

DF 4

DF 5

\begin{tabular}{|c|c|c|c|c|c|}
\hline \multicolumn{6}{|l|}{$\mathrm{P}_{\mathrm{c}}( \pm \mathrm{SE})$} \\
\hline Carpinus & $13680 \pm 8710$ & $39480 \pm 15460$ & $11280 \pm 5800$ & $21980 \pm 8340$ & $18810 \pm 7260$ \\
\hline Cercis & 4100 & 3857760 & 4370 & 32920 & 22170 \\
\hline Fagus & $7570 \pm 13820$ & $33080 \pm 9880$ & $7120 \pm 6530$ & $24710 \pm 5690$ & $18730 \pm 5710$ \\
\hline Juglans & $33890 \pm 6860$ & $-1530 \pm 32480$ & $19560 \pm 4000$ & $33490 \pm 8220$ & $24750 \pm 5120$ \\
\hline Pterocarya & $221270 \pm 3490$ & $-5030 \pm 526360$ & $121230 \pm 2140$ & $345360 \pm 28480$ & $183440 \pm 4820$ \\
\hline Quercus & $63740 \pm 3940$ & $29050 \pm 2870$ & $29830 \pm 2070$ & $24570 \pm 2000$ & $25530 \pm 1880$ \\
\hline Tilia begoniifolia & $89480 \pm 13780$ & $129780 \pm 40550$ & $54600 \pm 8360$ & $63660 \pm 12630$ & $53030 \pm 10100$ \\
\hline Tilia tomentosa & $34630 \pm 14210$ & $25290 \pm 8270$ & $19530 \pm 7610$ & $19290 \pm 4530$ & $17900 \pm 3350$ \\
\hline \multicolumn{6}{|l|}{$\mathrm{C}_{\mathrm{r}}$} \\
\hline Carpinus & 1790 & -170 & 1390 & 625 & 900 \\
\hline Cercis & 25 & -50 & 25 & 10 & 5 \\
\hline Fagus & 3365 & -2010 & 2460 & -1195 & -185 \\
\hline Juglans & 70 & 120 & 55 & 10 & 45 \\
\hline Pterocarya & 155 & 845 & 135 & 35 & 115 \\
\hline Quercus & 225 & 45 & 140 & 115 & -445 \\
\hline Tilia begoniifolia & 210 & 200 & 180 & 270 & 345 \\
\hline Tilia tomentosa & -30 & 5 & -30 & -20 & -40 \\
\hline \multicolumn{6}{|c|}{ Correlation coefficient $(r)$} \\
\hline Carpinus & 0.43 & $0.61 *$ & 0.51 & $0.62 *$ & $0.62 *$ \\
\hline Fagus & 0.18 & $0.75^{* *}$ & 0.34 & $0.82 * *$ & $0.74 * *$ \\
\hline Juglans & $0.86^{* * *}$ & 0.02 & $0.85^{* * *}$ & $0.81 * *$ & $0.85^{* * *}$ \\
\hline Pterocarya & $0.99 * * *$ & 0 & $0.99 * * *$ & $0.98 * * *$ & $0.99^{* * *}$ \\
\hline Quercus & $0.98 * * *$ & $0.95^{* * *}$ & $0.98 * * *$ & $0.97 * * *$ & $0.97 * * *$ \\
\hline Tilia begoniifolia & $0.93 * * *$ & $0.77 *$ & $0.93 * * *$ & $0.89 * *$ & $0.89 * *$ \\
\hline Tilia tomentosa & 0.87 & 0.91 & 0.88 & 0.95 & $0.97 *$ \\
\hline \multicolumn{6}{|l|}{$\mathrm{APP}( \pm \mathrm{SE})$} \\
\hline Aesculus & 9480 & 15559710 & 8760 & 46570 & 23970 \\
\hline Carpinus & $23960 \pm 7360$ & $37750 \pm 7330$ & $16950 \pm 4280$ & $25910 \pm 5060$ & $23830 \pm 4850$ \\
\hline Cercis & 4250 & 4089170 & 4520 & 33350 & 22320 \\
\hline Fagus & $34250 \pm 13450$ & $22820 \pm 3210$ & $16120 \pm 3970$ & $19740 \pm 2270$ & $18030 \pm 2390$ \\
\hline Juglans & $46140 \pm 8800$ & $39360 \pm 12190$ & $25960 \pm 4140$ & $35780 \pm 4660$ & $31700 \pm 4510$ \\
\hline Pterocarya & $227170 \pm 6460$ & $205670 \pm 498170$ & $124140 \pm 3320$ & $347690 \pm 24450$ & $187210 \pm 5420$ \\
\hline Quercus & $66340 \pm 3440$ & $29310 \pm 2250$ & $30610 \pm 1690$ & $25100 \pm 1610$ & $23220 \pm 1530$ \\
\hline Tilia begoniifolia & $96580 \pm 10490$ & $141850 \pm 27440$ & $58280 \pm 8210$ & $70350 \pm 9690$ & $59970 \pm 8330$ \\
\hline Tilia tomentosa & $32410 \pm 6570$ & $25620 \pm 4230$ & $18250 \pm 3550$ & $18420 \pm 2280$ & $16420 \pm 1730$ \\
\hline \multicolumn{6}{|c|}{ Correlation difference } \\
\hline Carpinus & 0.43 & 0 & 0.15 & 0.02 & 0.05 \\
\hline Fagus & 0.18 & 0.04 & 0.34 & 0.02 & 0 \\
\hline Juglans & 0.27 & 0.02 & 0.14 & 0 & 0.09 \\
\hline Pterocarya & 0 & 0 & 0 & 0 & 0 \\
\hline Quercus & 0 & 0 & 0.01 & 0.01 & 0.01 \\
\hline Tilia begoniifolia & 0.01 & 0.01 & 0.01 & 0.02 & 0.02 \\
\hline Tilia tomentosa & 0 & 0 & 0 & 0 & 0.01 \\
\hline \multicolumn{6}{|c|}{ RPP relative to Quercus } \\
\hline Aesculus & 0.14 & 530.87 & 0.29 & 1.86 & 1.03 \\
\hline Carpinus & 0.36 & 1.29 & 0.55 & 1.03 & 1.03 \\
\hline Cercis & 0.06 & 139.51 & 0.15 & 1.33 & 0.96 \\
\hline Fagus & 0.52 & 0.78 & 0.53 & 0.79 & 0.78 \\
\hline Juglans & 0.70 & 1.34 & 0.85 & 1.43 & 1.37 \\
\hline Pterocarya & 3.42 & 7.02 & 4.06 & 13.85 & 8.06 \\
\hline Quercus & 1 & 1 & 1 & 1 & 1 \\
\hline Tilia begoniifolia & 1.46 & 4.84 & 1.90 & 2.80 & 2.58 \\
\hline Tilia tomentosa & 0.49 & 0.87 & 0.60 & 0.73 & 0.71 \\
\hline
\end{tabular}

${ }^{*} p<0.05,{ }^{* *} p<0.01,{ }^{* * *} p<0.001$ 
Table 4. Potential pollen loadings ( \pm standard error) at the centre of the Ispani-II mire for the four taxa reconstructed using each dispersal function (DF - see text). Each taxon's potential pollen loading may be divided by that of a reference taxon (e.g. Quercus) to obtain correction factors for similarly sized basins; raw pollen data can then be divided by these correction factors prior to percentage calculation to obtain approximations of relative vegetation cover (see Sjögren et al. 2008).

\begin{tabular}{lccccc} 
& DF 1 & DF 2 & DF 3 & DF 4 & DF 5 \\
\hline Carpinus & $2230 \pm 690$ & $27900 \pm 5420$ & $7080 \pm 1790$ & $15940 \pm 3110$ & $14740 \pm 1790$ \\
Fagus & $1180 \pm 460$ & $18760 \pm 2640$ & $6540 \pm 1610$ & $11970 \pm 1380$ & $9790 \pm 700$ \\
Pterocarya & $21160 \pm 600$ & $152000 \pm 368160$ & $51820 \pm 1390$ & $213850 \pm 15040$ & $115760 \pm 2000$ \\
Quercus & $8920 \pm 460$ & $20070 \pm 1540$ & $12760 \pm 700$ & $15170 \pm 970$ & $14930 \pm 600$
\end{tabular}

\section{Figure captions}

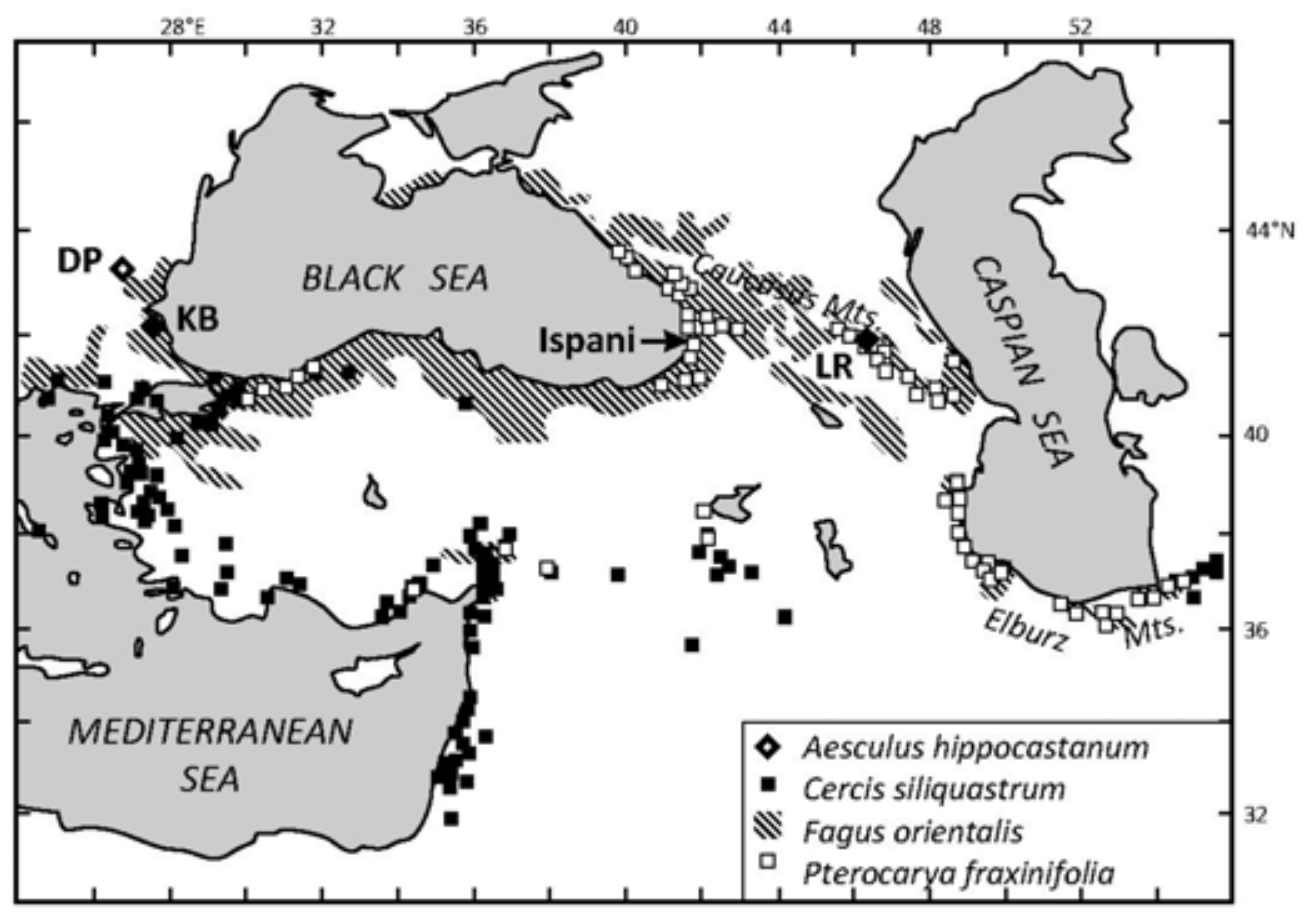

Figure 1. Map showing pollen trap locations studied in this paper and the distribution of some Tertiary-relict taxa in the Black Sea region (adapted from Browicz 1982). Pollen trapping sites denoted by diamonds: DP - Dervisha and Patleyna, Bulgaria; KB Kosti and Brodilovo, Bulgaria; LR - Lagodekhi Reservation, Georgia. The location of the Ispani-II mire is also shown. 

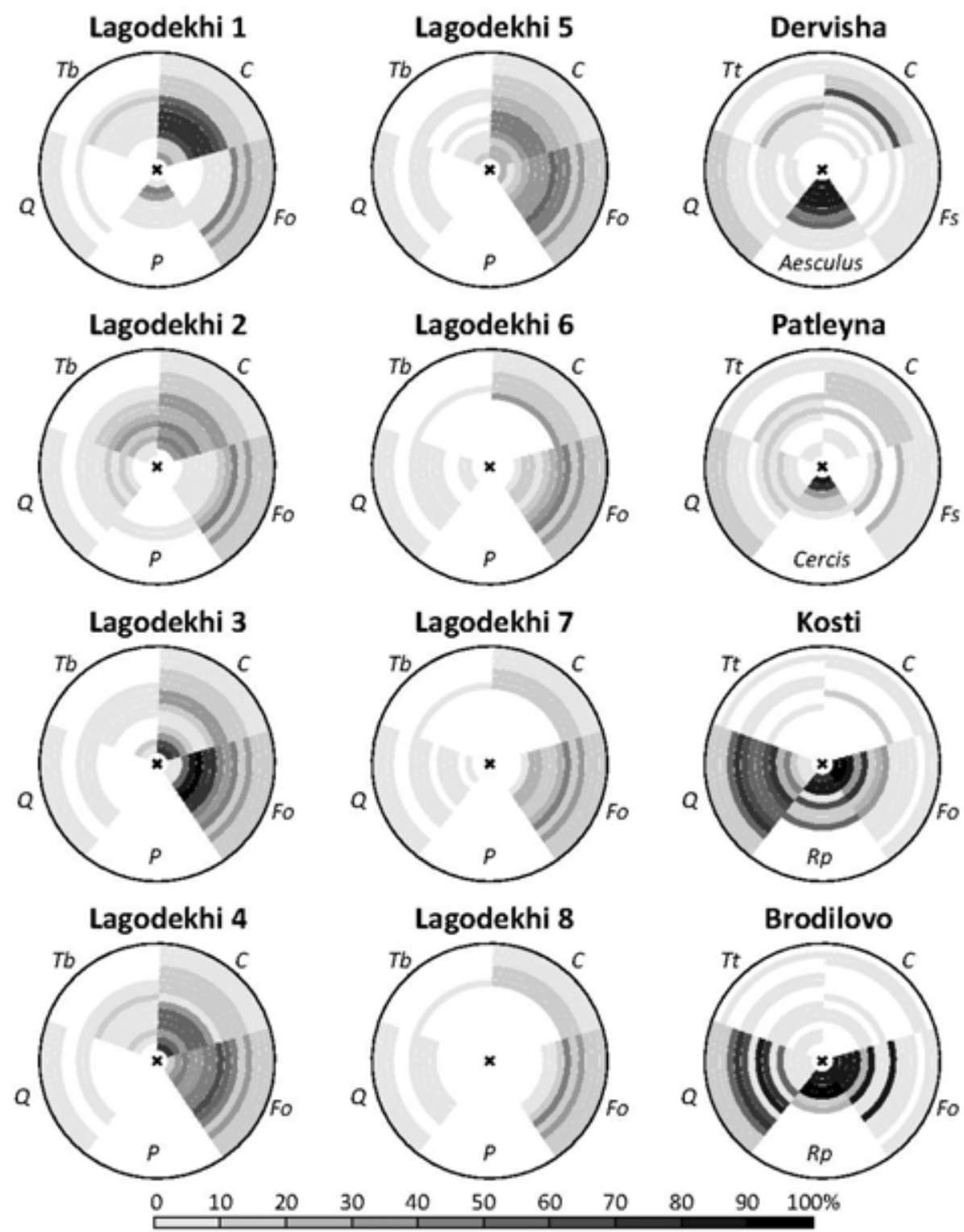

Figure 2. Schematic representation of plant cover abundance around the Georgian and Bulgarian pollen traps. Vegetation rings from $5 \mathrm{~m}$ to $232 \mathrm{~km}$ radius are shown around each trap location (denoted by ' $\times$ '), with the cover of 5 selected taxa indicated by shading: $C=$ Carpinus betulus, $F o=$ Fagus orientalis, $F s=F$. sylvatica, $P=$ Pterocarya fraxinifolia, $Q=$ Quercus spp., $R p=$ Rhododendron ponticum, $T b=$ Tilia begoniifolia, $T t=T$. tomentosa. Lagodekhi trap 9 (alpine zone) has the same tree cover as trap 8 with the rings shifted outward by $1.4 \mathrm{~km}$. 

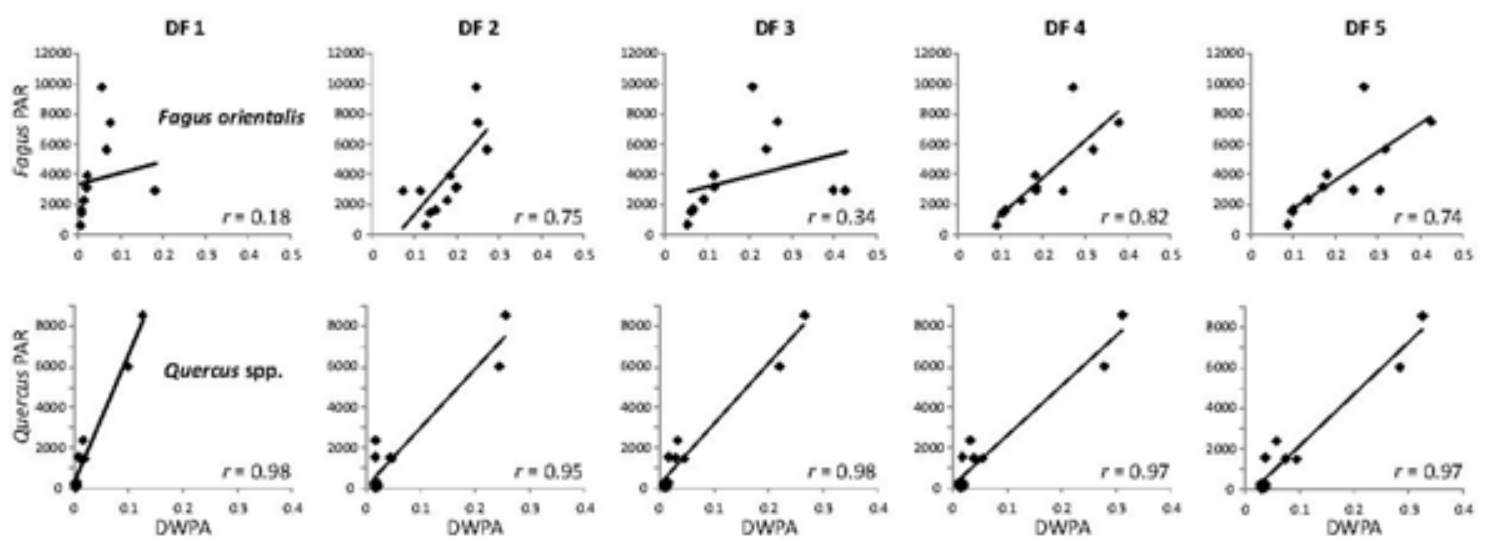

Figure 3. Relationships between average pollen accumulation rates (PAR) and distance-weighted plant abundance (DWPA) for Fagus orientalis and Quercus spp., produced using each of the five dispersal functions (DF). Correlation coefficients $(r)$ are given for each of the linear regression lines.

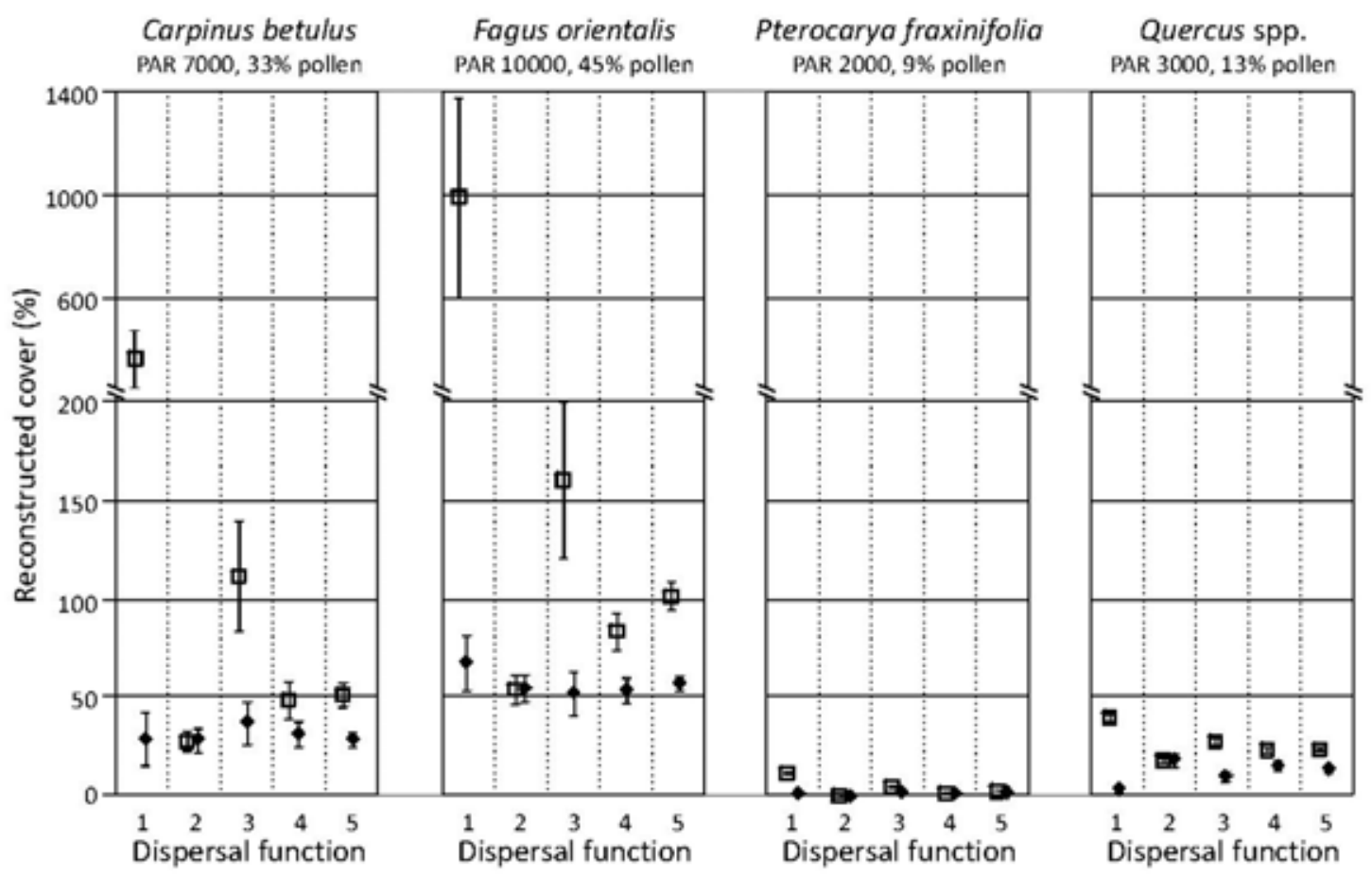

Figure 4. Reconstructions of Carpinus, Fagus, Pterocarya and Quercus cover around Ispani-II (Western Georgia) for approx. 1000-100 cal. yr BP. Estimates obtained by dividing mean pollen accumulation rates (PAR) by potential pollen loadings (Table 4) are indicated by open squares ( $\square$ ). These reconstructions may exceed $100 \%$ because the estimates are open-ended. Relative reconstructions, indicated by closed diamonds $(\diamond)$, 
are constrained by the assumption that $100 \%$ of the vegetation is comprised of the four taxa and thus indicate forest composition rather than cover abundance senso stricto. Error bars indicate standard errors in the reconstruction method. Average PARs and average pollen percentages for the period 1000-100 cal. yr BP are given above the graphs. 